\title{
Synthesis, antispasmodic and antidiarrheal activities of some 1-substituted imidazole derivatives
}

\author{
BASKAR LAKSHMANAN* \\ PAPIYA MITRA MAZUMDER \\ DINAKAR SASMAL \\ SWASTIKA GANGULY \\ Department of Pharmaceutical Sciences \\ Birla Institute of Technology, Mesra \\ Ranchi, Jharkhand-835215, India
}

Accepted April 4, 2011

\begin{abstract}
A series of 1-substituted imidazoles $\mathbf{1 a - d}$ and $\mathbf{2 a - d}$ were synthesized and screened for antispasmodic and antidiarrheal activities. Antispasmodic activity was tested at various concentrations on isolated tissue preparations; concentration-response curves were plotted and compared with atropine. All compounds were found to inhibit contraction of the guinea pig ileum. Castor oil-induced diarrhea model in rats was used for evaluation of antidiarrheal activity. Parameters such as intestinal transit and volume of intestinal fluid were measured for antidiarrheal activity at $40 \mathrm{mg} \mathrm{kg}^{-1}$ dose and compared with the standard drug loperamide at $6 \mathrm{mg} \mathrm{kg}^{-1}$ dose. Defecation frequency in the test group was found to be significantly lower $(p<0.01)$ compared to the control group and comparable with that of the standard. The present study reveals that the compounds exert antidiarrheal activity through possible inhibition of intestinal movement and reduction of capillary permeability in the abdominal cavity.
\end{abstract}

Keywords: 1-substituted imidazoles, antispasmodic, antidiarrheal, gastro-intestinal transit

Irritable bowel syndrome (IBS) is a disorder associated with muscarinic receptors $\left(\mathrm{M}_{3}\right)$ and characterized by cramping, abdominal pain, bloating, constipation and/or diarrhea $(1,2)$. Pain and intestinal spasms are the common state in chronic colon conditions such as irritable bowel syndrome, diverticulitis, and colitis. The muscarinic antagonistic activities, mediated by $\mathrm{M}_{3}$ receptors, are responsible for the smooth muscle spasm $(3,4)$. Antispasmodics are the most commonly used drugs, of which antimuscarinic agents are an important class. However, the efficacy of these agents is significantly limited due to lack of receptor subtype selectivity, resulting in unacceptable atropine-like side effects.

$\mathrm{M}_{3}$-selective antimuscarinic agents were sucessfully used in the treatment of IBS with minimal atropine-like side effects (5).

\footnotetext{
* Correspondence; e-mail: lbaskii@gmail.com
} 
Imidazole nucleus has been proven to have a number of medicinal properties (antiprotozoal, mutagenic, anticancer, antiviral, enzyme inhibition, $\mathrm{H}_{2}$-antagonism, $\alpha$-adrenergic agonism and $\beta$-blocking, anticonvulsant, antibacterial and antifungal) and has been also reported to have antimuscarinic activity (6). Against this background, the present study explores the possibility of imidazoles as $\mathrm{M}_{3}$-selective antagonists.

A series of 1-substituted imidazoles were synthesized and evaluated for their antispasmodic activity on isolated guinea pig ileum and antidiarrheal activity on castor oil-induced diarrhea on a rat model, respectively. As a result, these 1-substituted imidazoles might possibly lead to the development of compounds with probable muscarinic $\left(\mathrm{M}_{3}\right)$ antagonistic activity, especially to relieve pain in smooth muscles in conditions such as diarrhea and gastrointestinal disorders.

\section{EXPERIMENTAL}

Melting points were determined in open glass capillaries using an Electro thermal IA 9000 SERIES digital melting point apparatus (Electrothermal, UK) and are uncorrected. FT-IR spectra were taken on an IR-Prestige 21 (Shimadzu, Japan) from $4000-400 \mathrm{~cm}^{-1}$ using potassium bromide discs. ${ }^{1} \mathrm{H}$ NMR spectra were recorded at $300 \mathrm{MHz}$ on a Bruker DRX-300 instrument (Bruker Instruments Inc., USA) using $\mathrm{CDCl}_{3}$ as solvent (7). Chemical shifts were measured at $\delta$ units (ppm) relative to tetramethylsilane (TMS). Mass spectra were taken on a JEOL AccuTOF-DART mass spectrometer (Japan). Elemental analyses were performed on a Vario EL III Elemental Analyser (Elementar, Germany) using sulfanilamide as standard. In the elemental analysis, the observed values were within \pm $0.4 \%$ of the calculated values. The purity of all compounds was established by a single spot on TLC plates (Merck, Germany). Iodine vapors were used as the developing agent and the solvent system used for the TLC analysis was benzene and ethanol (8:2). Imidazole, 2-methyl imidazole and para-substituted phenacyl bromides were procured from Sigma-Aldrich, USA. Acetylcholine hydrochloride (Hi-media, India), atropine sulfate (Hi-media) and loperamide hydrochloride (Torrent, India), and all other chemicals used in the study were of analytical grade.

The synthetic pathways for compounds $1 \mathbf{1 a}-\mathbf{d}$ and $\mathbf{2 a - d}$ are given in Scheme $1(8,9)$.

Synthesis of 1-(4-substituted-phenyl)-2-(2-methyl-1H-imidazol-1-yl)ethanone (1a-d) and 1-(4-substituted phenyl)-2-(1H-imidazol-1-yl) ethanone (2a-d). - To a solution of imidazole/2-methylimidazole $(0.03 \mathrm{~mol}, 2.46 \mathrm{~g} / 0.03 \mathrm{~mol}, 2.04 \mathrm{~g})$ in dry DMF (10 mL) a solution of appropriate para-substituted phenacyl bromide $(0.002 \mathrm{~mol}, 0.46 \mathrm{~g})$ in $10 \mathrm{~mL}$ of dry DMF was added dropwise at a temperature of $5-10{ }^{\circ} \mathrm{C}$, with stirring. The stirring was continued for another $3-6 \mathrm{~h}$ at the same temperature. Then the mixture was poured into cold water $(20 \mathrm{~mL})$ and stirred for another hour. The precipitate obtained was removed by filtration and the filtrate was extracted with benzene. Upon evaporation of organic layer, compounds $\mathbf{1} \mathbf{a}-\mathbf{d}$ and $\mathbf{2 a - d}$ were obtained as a crystalline mass and were recrystallized from benzene/ethanol $(8,9)$. 


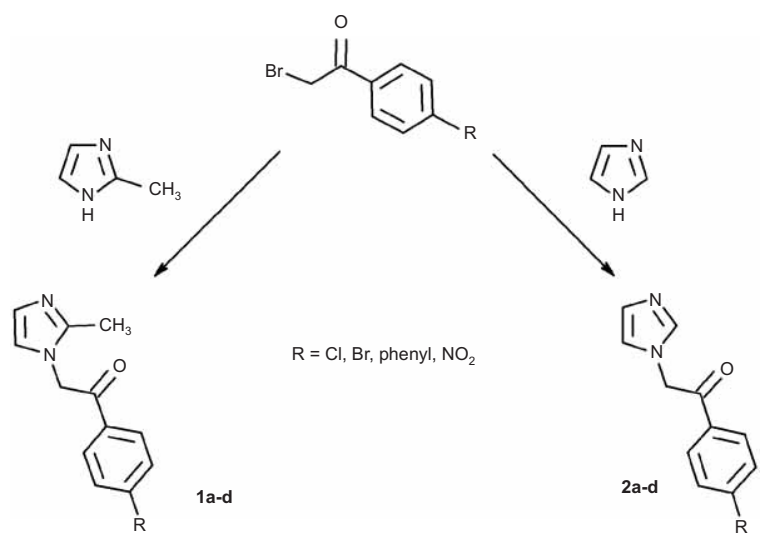

Scheme 1.

\section{Pharmacological evaluation}

Isolated tissue preparation. - Male albino guinea pigs (weighing 370-450 g) were kept fasting for $18 \mathrm{~h}$ prior to commencement of the experiment and were given water ad libitum. They were then sacrificed by a blow on the head and exsanguinated as per CPCSEA recommended guidelines with the Institutional Animal Ethics Committee (Birla Institute of Technology, Mesra, Ranchi, India) approval for animal experimentation. The caecum was lifted and the ileocaecal junction was identified (10). The ileum was cut at this point and transferred to a dish containing tyrode solution (11). A terminal segment of ileum of about $1-1.5 \mathrm{~cm}$ was cut, and intestinal contents were removed and freed from mesenteric attachments. A thread was tied at each end of the tissue taking care that ileum was left open and the thread did not close the lumen (12). The tissue was mounted into a 30-mL organ bath filled with tyrode solution. The temperature was maintained at $37^{\circ} \mathrm{C}$ and oxygenated with a mixture of $95 \% \mathrm{O}_{2}$ and $5 \% \mathrm{CO}_{2}$ continuously. Initial tension was $1 \mathrm{~g}$ and stabilization time was $45-60 \mathrm{~min}$. Load was adjusted to $0.5 \mathrm{~g}$ and a bath volume of about $15 \mathrm{~mL}$ was maintained. The preparation was washed every $10 \mathrm{~min}$ with tyrode solution. After an initial equilibration period of about 30-45 min, increasing concentrations of acetylcholine hydrochloride $(0.1,0.2,0.4,0.8,1.6,3.2 \mathrm{~mL}$ of $10 \mu \mathrm{g} \mathrm{mL}-1$ ) were added to the bath and the concentration-response curve was recorded as a control with a contact time of 90 seconds. The height from the baseline was expressed as percent of the maximum response of acetylcholine (13).

Antispasmodic activity. - Antispasmodic (anticholinergic) effects of the test compounds (1a-d, 2a-d) were tested in guinea pig ileum prepared as described earlier. All the test compounds were suspended in aqueous Tween $80(2 \%, V / V)$ and the standard drug was dissolved in distilled water. Test drugs were studied at various concentrations (10, 50 and $100 \mu \mathrm{g} \mathrm{mL}^{-1}$ ) and atropine sulfate at $10 \mu \mathrm{g} \mathrm{mL}^{-1}$. A test drug or standard was added to the bath $5 \mathrm{~min}$ before the administration of acetylcholine hydrochloride. The ability of the test drug to antagonize acetylcholine induced contractions was recorded as changes in height with respect to the control. The concentration-response curve was constructed until the ceiling effect was obtained. Six graded-response curves were obtained 
for each preparation, with a 20 -min rest between each (14). The mean maximal response obtained from the first concentration-response curve (in the absence of lead compounds) was taken as the $100 \%$ response value (15). After completing the concentration-response curve, contractions were recorded using the frontal writing lever on kymograph. The kymogram was fixed with a fixing solution containing shellac and colophony in alcohol $(14,15)$.

Castor oil-induced diarrhea. - Male Wistar rats were screened initially by giving $1 \mathrm{~mL}$ of castor oil and only those showing diarrhea were selected and grouped for the final experiment. Each rat was randomly placed in an individual cage, the floor of which was lined with blotting paper. The floor lining was changed every hour. The animals were divided into their respective groups of six animals each. Each rat received $2 \mathrm{~mL}$ of castor oil orally $30 \mathrm{~min}$ before commencement of the experiment. All rats were orally treated with vehicle (aqueous Tween 80, $2 \%, V / V, 10 \mathrm{~mL} \mathrm{~kg}^{-1} \mathrm{bm}$ ), test compounds (1a-d and 2a-d, $40 \mathrm{mg} \mathrm{kg}^{-1} \mathrm{bm}$ ) and standard drug (loperamide, $6 \mathrm{mg} \mathrm{kg}^{-1} \mathrm{bm}$ ). After administration of the test drug/standard drug the animals were observed for a period of $6 \mathrm{~h}$. The number of diarrheic feces excreted by the animals (recorded as scores) and the cumulative mass of fecal matter collected over a period of $6 \mathrm{~h}$ were recorded. The changes in body mass between the pre- and post-experiment were also determined. The percent inhibition of defecation score and fecal mass was calculated $(16,17)$.

Intestinal transit and intestinal fluid. - Each rat in the experimental group was orally administered $2 \mathrm{~mL}$ of castor oil as described earlier in the castor oil-induced diarrhea method $(15,16)$. The rats were also given $10 \%$ activated charcoal in physiological saline in a volume of $3 \mathrm{~mL} \mathrm{~kg}^{-1}, 30 \mathrm{~min}$ after being given compounds 1 a-d and $\mathbf{2 a}-\mathbf{d}$ (40 mg $\left.\mathrm{kg}^{-1}\right)$ and loperamide $\left(6 \mathrm{mg} \mathrm{kg}^{-1}\right)$. Intestinal transit and the volume of intestinal fluid in rats were measured (18). The rats were anesthetized $15 \mathrm{~min}$ later by inhalation of ether and euthanized by cervical dislocation. The small intestine from the pylorus to the caecum was dissected. The individual distance travelled by the charcoal in centimetres divided by the total length of the intestines in centimetres (pylorus to caecum) was calculated for each rat and expressed as percentage. Intestinal fluid accumulation was determined by castor oil-induced enteropooling method. Intestinal contents were collected into a graduated tube and their volume was measured (19).

\section{Statistical analysis}

Results were expressed as mean \pm SEM. Statistical significance was determined by the one-way analysis of variance (ANOVA) followed by Dunnett's test.

\section{RESULTS AND DISCUSSION}

\section{Chemistry}

Formation of compounds $1 \mathbf{a}-\mathbf{d}$ and $\mathbf{2 a - d}$ was confirmed by the presence of characteristic bands for $\mathrm{C}-\mathrm{N}$ stretching at $3400-3100 \mathrm{~cm}^{-1}$ and $\mathrm{C}=\mathrm{O}$ stretch at $1610-1680 \mathrm{~cm}^{-1}$ in the IR spectrum. Compound 1a, as a representative of imidazoles, showed $\mathrm{m} / \mathrm{z} 235$ $(\mathrm{M}+1)^{+}$and compound 2a, which represented 2-methylimidazoles, showed $\mathrm{m} / \mathrm{z} 221$ $(\mathrm{M}+1)^{+} .{ }^{1} \mathrm{H}$ NMR spectra of 1 a-d displayed a singlet for methyl protons at 2.309-2.336 
B. Lakshmanan et al.: Synthesis, antispasmodic and antidiarrheal activities of some 1-substituted imidazole derivatives, Acta Pharm. 61 (2011) 227-236.

ppm. Protons of methylene group appeared at 5.266-5.348 ppm as singlets. Protons of imidazole displayed a doublet at 7.71-8.10 ppm, and aromatic protons of phenyl group displayed a multiplet at 6.80-7.50 ppm. Elemental analysis data together with ${ }^{1} \mathrm{H}$ NMR data supported the proposed structure for compounds $\mathbf{1 a - d}$ and $\mathbf{2 a - d}$ (Tables I and II).

Table I. Physicochemical data of synthesized compounds

\begin{tabular}{|c|c|c|c|c|c|c|c|c|}
\hline \multirow{2}{*}{ Compd. } & \multirow[t]{2}{*}{$\mathrm{R}$} & \multirow{2}{*}{$\begin{array}{l}\text { Molecular } \\
\text { formula }\end{array}$} & \multirow{2}{*}{$\begin{array}{l}\text { Molecular } \\
\text { mass, } M_{\mathrm{r}}\end{array}$} & \multirow{2}{*}{$\begin{array}{c}\text { Yield } \\
(\%)\end{array}$} & \multirow{2}{*}{$\begin{array}{l}\text { M.p. } \\
\left({ }^{\circ} \mathrm{C}\right)\end{array}$} & \multicolumn{3}{|c|}{$\begin{array}{l}\text { Elemental analysis } \\
\text { Calcd./found (\%) }\end{array}$} \\
\hline & & & & & & $\mathrm{C}$ & $\mathrm{H}$ & $\mathrm{N}$ \\
\hline 1a & $\mathrm{Cl}$ & $\mathrm{C}_{12} \mathrm{H}_{11} \mathrm{ClN}_{2} \mathrm{O}$ & 234.68 & 55 & $149-152$ & $61.41 / 61.38$ & $4.72 / 4.66$ & $11.94 / 11.86$ \\
\hline $1 b$ & $\mathrm{Br}$ & $\mathrm{C}_{12} \mathrm{H}_{11} \mathrm{BrN}_{2} \mathrm{O}$ & 279.13 & 41 & 186-188 & $51.63 / 51.49$ & $3.97 / 3.87$ & $10.04 / 09.94$ \\
\hline $1 c$ & $\mathrm{C}_{6} \mathrm{H}_{5}$ & $\mathrm{C}_{18} \mathrm{H}_{16} \mathrm{~N}_{2} \mathrm{O}$ & 276.33 & 58 & 182-185 & $78.24 / 78.13$ & $5.84 / 5.76$ & $10.14 / 10.11$ \\
\hline $1 d$ & $\mathrm{NO}_{2}$ & $\mathrm{C}_{12} \mathrm{H}_{11} \mathrm{~N}_{3} \mathrm{O}_{3}$ & 245.23 & 64 & 194-196 & $58.77 / 58.59$ & $4.52 / 4.42$ & $17.13 / 17.09$ \\
\hline $2 a$ & $\mathrm{Cl}$ & $\mathrm{C}_{11} \mathrm{H}_{9} \mathrm{ClN}_{2} \mathrm{O}$ & 220.65 & 52 & $132-135$ & $61.41 / 61.39$ & $4.72 / 4.67$ & $11.94 / 11.83$ \\
\hline $2 b$ & $\mathrm{Br}$ & $\mathrm{C}_{11} \mathrm{H}_{9} \mathrm{BrN}_{2} \mathrm{O}$ & 265.10 & 59 & $142-144$ & $49.84 / 49.79$ & $3.42 / 3.35$ & $10.57 / 10.43$ \\
\hline $2 c$ & $\mathrm{C}_{6} \mathrm{H}_{5}$ & $\mathrm{C}_{17} \mathrm{H}_{14} \mathrm{~N}_{2} \mathrm{O}$ & 262.30 & 66 & $164-166$ & $77.84 / 77.76$ & $5.38 / 5.25$ & $10.68 / 10.56$ \\
\hline $2 \mathrm{~d}$ & $\mathrm{NO}_{2}$ & $\mathrm{C}_{11} \mathrm{H}_{9} \mathrm{~N}_{3} \mathrm{O}_{3}$ & 231.20 & 62 & $152-154$ & $57.14 / 57.11$ & $3.92 / 3.79$ & $18.17 / 18.03$ \\
\hline
\end{tabular}

Table II. Spectral data of synthesized compounds

\begin{tabular}{|c|c|c|c|}
\hline Compd. & $\operatorname{IR}\left(v, \mathrm{~cm}^{-1}\right)$ & ${ }^{1} \mathrm{H}$ NMR $(300 \mathrm{MHz}, \delta, \mathrm{ppm})\left(\mathrm{DMSO}^{\left.-\mathrm{d}_{6}\right)}\right.$ & DART-MS $(m / z)$ \\
\hline 1a & $\begin{array}{l}2964,1288, \\
1496,1691,827 \\
669\end{array}$ & $\begin{array}{l}2.3\left(\mathrm{~s}, 3 \mathrm{H},-\mathrm{CH}_{3}\right), 5.27\left(\mathrm{~s}, 2 \mathrm{H},-\mathrm{CH}_{2}\right) \\
7-7.4(\mathrm{~m}, 4 \mathrm{H}, \mathrm{Ar}-\mathrm{H}), 7.5(\mathrm{~d}, 1 \mathrm{H}, \text { Het-H }) \\
7.9(\mathrm{~d}, 1 \mathrm{H}, \text { Het-H })\end{array}$ & $235(\mathrm{M}+\mathrm{H})^{+}$ \\
\hline $1 \mathrm{~b}$ & $\begin{array}{l}2960,1226, \\
1436,1691,823 \\
563\end{array}$ & $\begin{array}{l}2.3\left(\mathrm{~s}, 3 \mathrm{H},-\mathrm{CH}_{3}\right), 5.26\left(\mathrm{~s}, 2 \mathrm{H}, \mathrm{CH}_{2}\right) \\
7-7.6(\mathrm{~m}, 4 \mathrm{H}, \mathrm{Ar}-\mathrm{H}), 7.7(\mathrm{~d}, 1 \mathrm{H}, \text { Het-H }) \\
7.8(\mathrm{~d}, 1 \mathrm{H}, \text { Het-H })\end{array}$ & $279(\mathrm{M}+\mathrm{H})^{+}$ \\
\hline 1c & $\begin{array}{l}2960,1224 \\
1693,1494,846 \\
767\end{array}$ & $\begin{array}{l}2.44\left(\mathrm{~s}, 3 \mathrm{H},-\mathrm{CH}_{3}\right), 5.348\left(\mathrm{~s}, 2 \mathrm{H},-\mathrm{CH}_{2}\right), 6.8-7.2 \\
(\mathrm{~m}, 9 \mathrm{H}, \mathrm{Ar}-\mathrm{H}), 8.1(\mathrm{~d}, 1 \mathrm{H}, \text { Het-H), } 8.3(\mathrm{~d}, 1 \mathrm{H}, \\
\text { Het-H) }\end{array}$ & $277(\mathrm{M}+\mathrm{H}, \mathrm{bp})^{+}$ \\
\hline 1d & $\begin{array}{l}3088,1217, \\
1435,1691,825 \\
1517\end{array}$ & $\begin{array}{l}2.34\left(\mathrm{~s}, 3 \mathrm{H},-\mathrm{CH}_{3}\right), 5.34\left(\mathrm{~s}, 2 \mathrm{H}, \mathrm{CH}_{2}\right) \\
7.2-7.5(\mathrm{~m}, 4 \mathrm{H}, \mathrm{Ar}-\mathrm{H}), 7.6(\mathrm{~d}, 1 \mathrm{H}, \text { Het- } \mathrm{H}) \\
7.7(\mathrm{~d}, 1 \mathrm{H}, \text { Het-H) }\end{array}$ & $246(\mathrm{M}+\mathrm{H}, \mathrm{bp})^{+}$ \\
\hline $2 a$ & $\begin{array}{l}3018,1493 \\
1680,842,684\end{array}$ & $\begin{array}{l}5.37\left(\mathrm{~s}, 2 \mathrm{H},-\mathrm{CH}_{2}\right), 6.9-7.4(\mathrm{~m}, 4 \mathrm{H}, \mathrm{Ar}-\mathrm{H}) \\
7.5(\mathrm{~d}, 1 \mathrm{H}, \text { Het-H}), 7.9(1 \mathrm{H}, \mathrm{d}, \text { Het-H })\end{array}$ & $221(\mathrm{M}+\mathrm{H})^{+}$ \\
\hline $2 b$ & $\begin{array}{l}2999,1458 \\
1595,831,578\end{array}$ & $\begin{array}{l}5.364\left(\mathrm{~s}, 2 \mathrm{H},-\mathrm{CH}_{2}\right), 6.9-7.4(\mathrm{~m}, 4 \mathrm{H}, \mathrm{Ar}-\mathrm{H}), 7.7 \\
(\mathrm{~d}, 1 \mathrm{H}, \text { Het-H), } 7.8(\mathrm{~d}, 1 \mathrm{H}, \text { Het-H })\end{array}$ & $265(\mathrm{M}+\mathrm{H})^{+}$ \\
\hline $2 \mathrm{c}$ & $\begin{array}{l}3159,1514 \\
1593,815,748\end{array}$ & $\begin{array}{l}5.43\left(\mathrm{~s}, 2 \mathrm{H},-\mathrm{CH}_{2}\right), 7.3-7.5(\mathrm{~m}, 9 \mathrm{H}, \mathrm{Ar}-\mathrm{H}) \\
7.6(\mathrm{~d}, 1 \mathrm{H}, \text { Het-H), } 7.7(\mathrm{~d}, 1 \mathrm{H}, \text { Het-H }) \\
8.0(\mathrm{~s}, 1 \mathrm{H}, \text { Het-H })\end{array}$ & $263(\mathrm{M}+\mathrm{H})^{+}$ \\
\hline $2 d$ & $\begin{array}{l}3020,1464, \\
1678,828,1522\end{array}$ & $\begin{array}{l}5.66\left(2 \mathrm{H}, \mathrm{s},-\mathrm{CH}_{2}\right), 7.3-7.5(\mathrm{~m}, 4 \mathrm{H}, \mathrm{Ar}-\mathrm{H}) \\
7.6(\mathrm{~d}, 1 \mathrm{H}, \text { Het-H), } 8.2(\mathrm{~d}, 1 \mathrm{H}, \text { Het-H}) \\
8.3(\mathrm{~s}, 1 \mathrm{H}, \text { Het-H) }\end{array}$ & $232(\mathrm{M}+\mathrm{H})^{+}$ \\
\hline
\end{tabular}




\section{Antispasmodic activity}

Antagonistic activity of the compounds $\mathbf{1 a - d}$ and $\mathbf{2 a - d}$ was tested at various concentrations $\left(10,50\right.$ and $\left.100 \mu \mathrm{g} \mathrm{mL}^{-1}\right)$, and concentration-response curves were plotted to check the antagonistic activity of the compounds against acetylcholine (13). All the compounds at $100 \mu \mathrm{g} \mathrm{mL}^{-1}$ significantly $(p<0.05)$ antagonized the contraction of guinea pig ileum, in a competitive and concentration-dependent manner. This is manifested by plotting pM values (4.78-6.26); a logarithmic conversion of the number of moles of acetylcholine present in the organ bath) against \% maximal response as shown in Fig. 1. (14).

All compounds were found to produce a competitive antagonistic action against acetylcholine at all three concentrations, which is probably mediated through muscarinic receptors present in the smooth muscle $\left(\mathrm{M}_{3}\right)$. The chloro- and nitro-substituted phenacyl imidazoles showed significant $(p<0.05)$ antagonistic action only at $100 \mu \mathrm{g} \mathrm{mL}-1$, whereas the bromo- and phenyl-substituted phenacyl imidazoles were found to be more effective in their antagonistic action at $50 \mu \mathrm{g} \mathrm{mL}-1$ compared to the chloro- and nitro-substituted compounds.

\section{Antidiarrheal activity}

Antidiarrheal activity of compounds $\mathbf{1 a - d}$ and $\mathbf{2 a - d}$ was tested at a concentration of $40 \mathrm{mg} \mathrm{kg}^{-1} \mathrm{bm}$ against loperamide at $6 \mathrm{mg} \mathrm{kg}^{-1} \mathrm{bm}$. The results of antidiarrheal study clearly showed that all compounds reduced the severity of diarrhea and fecal mass induced by castor oil. Compounds 1a, $\mathbf{1 d}$ and 2a showed significant $(p<0.01)$ inhibition against the control, whereas compounds $\mathbf{1 b}, \mathbf{1 c}, \mathbf{2 b}, \mathbf{2 c}$ and $\mathbf{2 d}$ showed comparable activity with that of the standard loperamide.

In intestinal transit and intestinal fluid accumulation, compounds $\mathbf{1 b}, \mathbf{2 c}$ and $\mathbf{2 d}$ produced significant inhibition $(p<0.01)$ against the control at $40 \mathrm{mg} \mathrm{kg}^{-1} \mathrm{bm}$. Compounds 1a, 1c, 1d and 2a produced significant $(p<0.05)$ inhibition against the control. Amongst all, compound $\mathbf{2} \mathbf{b}$ showed marked inhibition $(p<0.001)$, which was comparable with loperamide.
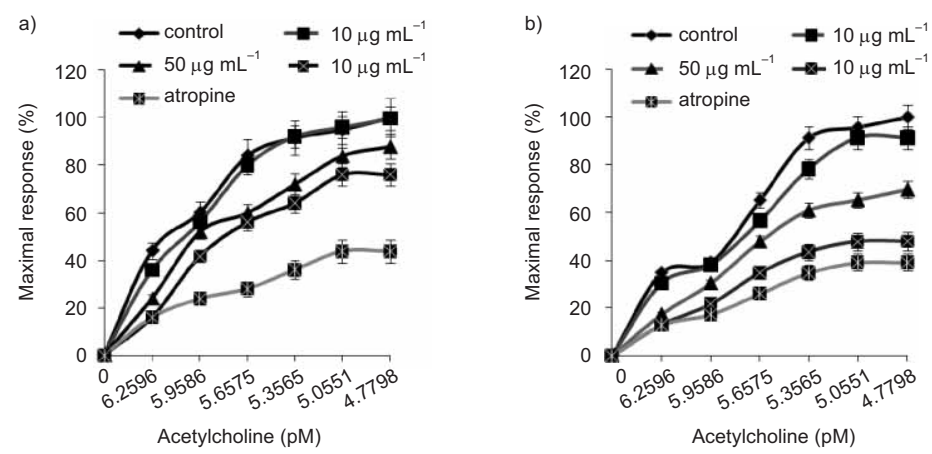

Fig. 1. The contractile response elicited by acetylcholine on guinea pig ileum in the presence and in the absence of atropine and compounds: a) $1 \mathrm{a}$ and b) $1 \mathrm{~b}$. pM: $-\log n$ (acetylcholine) (mean \pm S.E.M, $n=6)$ in the organe bath. 


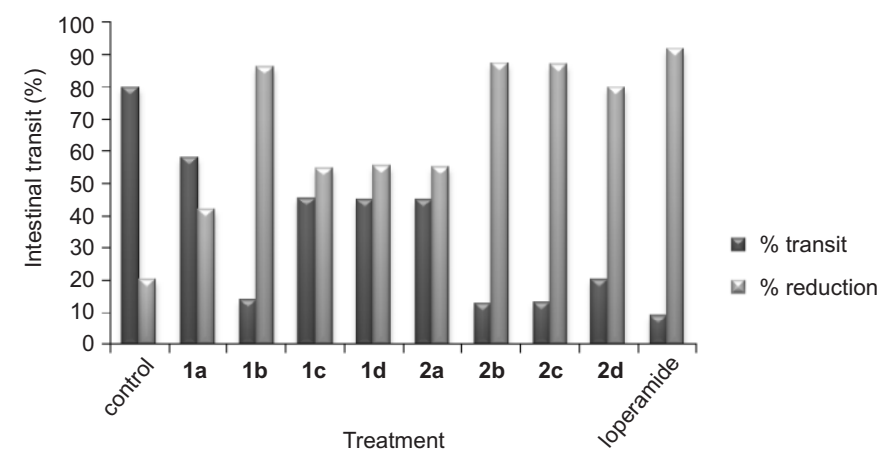

Fig. 2. Effect of compounds 1a-d and 2 a-d $\left(40 \mathrm{mg} \mathrm{kg}^{-1}\right)$ and loperamide $\left(6 \mathrm{mg} \mathrm{kg}^{-1}\right)$ on intestinal transit and reduction in the castor oil-induced diarrhea in rats.

Since 1-substituted imidazoles successfully inhibited the castor oil-induced diarrhea, it can be assumed that the antidiarrheal action was mediated by an antisecretory mechanism (18) and also decreased the intestinal muscle tone and peristalsis of the gastro-intestinal tract by slowing the movement of fecal matter through the gastro-intestinal tract. This was also evident from the reduction of the total number of copious feces in test groups.

\section{Structure activity relation}

All the compounds exhibited dose-dependent antispasmodic activity, as evident from the maximal response percentage (Fig. 1). Imidazole derivatives without methyl substi-

Table III. Effect of test compounds $\left(40 \mathrm{mg} \mathrm{kg}^{-1}\right)$ and loperamide $\left(6 \mathrm{mg} \mathrm{kg}^{-1}\right)$ on castor oil-induced diarrhea in rats

\begin{tabular}{cccc}
\hline Treatment & Total score (inhibition, \%) & Fecal mass (inhibition, \%) & Change in body mass (\%) \\
\hline Control & 0 & 0 & $1.1 \pm 0.2$ \\
1a & $59.1^{\mathrm{c}}$ & $53.5^{\mathrm{c}}$ & $0.7 \pm 0.2$ \\
$\mathbf{1 b}$ & $76.0^{\mathrm{d}}$ & $74.0^{\mathrm{d}}$ & $0.3 \pm 0.1$ \\
$\mathbf{1 c}$ & $72.3^{\mathrm{d}}$ & $69.8^{\mathrm{d}}$ & $0.4 \pm 0.2$ \\
$\mathbf{1 d}$ & $58.0^{\mathrm{c}}$ & $57.0^{\mathrm{c}}$ & $0.4 \pm 0.1$ \\
$\mathbf{2 a}$ & $65.1^{\mathrm{c}}$ & $65.2^{\mathrm{c}}$ & $0.5 \pm 0.2$ \\
$\mathbf{2 b}$ & $83.1^{\mathrm{d}}$ & $82.0^{\mathrm{d}}$ & $0.3 \pm 0.1$ \\
$\mathbf{2 c}$ & $81.0^{\mathrm{d}}$ & $78.3^{\mathrm{d}}$ & $0.3 \pm 0.1$ \\
$\mathbf{2 d}$ & $77.1^{\mathrm{c}}$ & $77.0^{\mathrm{d}}$ & $0.4 \pm 0.1$ \\
Loperamide & $98.0^{\mathrm{d}}$ & $97.0^{\mathrm{d}}$ & $0.1 \pm 0.1$ \\
\hline
\end{tabular}

a Test compounds: $40 \mathrm{mg} \mathrm{kg}^{-1} \mathrm{bm}$, loperamide $\left(6 \mathrm{mg} \mathrm{kg}^{-1} \mathrm{bm}\right)$.

$\mathrm{b}$ Values are mean $\pm \mathrm{SEM}, n=6$.

c Significantly different from loperamide $(p<0.05)$.

d Significantly different from the control $(p<0.01)$. 
tution at the $2^{\text {nd }}$ position (2a-d) have shown better antispasmodic activity. The same applies to antidiarrheal activity. Amongst the four electron withdrawing groups as substituents studied at para position of phenyl ring (chloro, bromo, phenyl and nitro), the bromo derivatives $(\mathbf{2} \mathbf{b}$ and $\mathbf{1 b})$ have shown the highest antidiarrheal activity. The antidiarrheal activity profile can be summarized as: $\mathbf{2 b}>\mathbf{1 b}>\mathbf{2 c}>\mathbf{2 d}>\mathbf{1 c}>\mathbf{1 d}>\mathbf{2 a}>\mathbf{1 a}$ and is evident from the percentage inhibition (Table III).

\section{CONCLUSIONS}

It is evident from the present findings that the synthesized 1-substituted imidazoles 1a-d and 2a-d showed marked muscarinic anticholinergic activity in isolated guinea pig ileum. In this work, the 1-substituted imidazoles were found to possess relaxant activity on the guinea pig ileum smooth muscle spasm produced by acetylcholine and to inhibit the castor oil-induced diarrhoea in rats with a significant antidiarrheal effect. These findings could be utilized to design compounds with superior activity in promoting antidiarrheal effect in conditions like cramping, abdominal pain, bloating, constipation and diarrhea.

Acknowledgements. - Authors are thankful to the Department of Pharmaceutical Sciences, Birla Institute of Technology, and Ranchi, India, for providing research facilities for this work. The corresponding author is thankful to AICTE, Quality Improvement Programme (New Delhi), for the financial assistance provided during the course of this research work.

\section{REFERENCES}

1. H. Miyachi, H. Kiyota and M. Segawa, Novel imidazole derivatives with subtype-selective antimuscarinic activity, Bioorg. Med. Chem. Lett. 8 (1998) 1807-1812; DOI: 10.106/S0960-894X (98) 00312-6.

2. H. Miyachi, H. Kiyota and M. Segawa, Novel imidazole derivatives with subtype-selective antimuscarinic activity, Bioorg. Med. Chem. Lett. 8 (1998) 2163-2168; DOI: 10.1016/S0960-894X (98) 00393-X.

3. A. U. Khana and A. H. Gilania, Antispasmodic and bronchodilator activities of Artemisia vulgaris are mediated through dual blockade of muscarinic receptors and calcium influx, J. Ethnopharmacol. 126 (2009) 480-486; DOI: 10.1016/j.jep.2009.09.010.

4. Drug Discovery and Evaluation: Pharmacological assays, $2^{\text {nd }}$ (Eds. H. G. Vogel, W. H. Vogel, B. A. Scholkens, J. Sandow, G. Muller and F. W. Vogel) Springer, Berlin 2002, pp. 855-856.

5. S. Kobayashi, K. Ikeda, M. Suzuki, T. Yamada and K. Miyata, Effects of YM905, a novel muscarinic M3-receptor antagonist, on experimental models of bowel dysfunction in vivo, Jpn. J. Pharmacol. 86 (2001) 281-288; DOI: 10.1254/jjp.86.281.

6. M. T. Griffin, J. C. Hsu, D. Shehnaz and F. J. Ehlert, Comparison of the pharmacological antagonism of M2 and M3 muscarinic receptors expressed in isolation and in combination, Biochem. Pharmacol. 65 (2003) 1227-1241; DOI: 10.1016/S0006-2952(03)00068-6.

7. Y. K. A. Bouz, L. J. Wiak and J. B. Ejowski, ${ }^{1} \mathrm{H}$ and ${ }^{13} \mathrm{C}$ NMR spectroscopy of 9 -acridinones, J. Mol. Struct. 612 (2002) 29-38. 
8. D. Nardi, A. Tajana, A. Leonardi, R. Pennini, F. Portioli, M. J. Magistretti and A. Subbisi, Synthesis and anticonvulsant activity of N-(benzoylalkyl)imidazoles and N-( $\omega$-phenyl- $\omega$-hydroxyalkyl)imidazoles, J. Med. Chem. 24 (1981) 727-731; DOI: 10.1021/jm00138a017.

9. S. Ganguly and B. K. Razdan, Synthesis of some new derivatives of 2-methyl imidazoles, Indian J. Heterocycl. Chem. 14 (2005) 255-256.

10. F. Shamsa, A. Ahmadiani and R. Khosrokhavar, Antihistaminic and anticholinergic activity of barberry fruit (Berberis vulgaris) in the guinea-pig ileum, J. Ethnopharmacol. 64 (1999) 161-166; DOI: 10.1016/S0378-8741(98)00122-6.

11. S. K. Kulkarni, Handbook of Experimental Pharmacology, $3^{\text {rd }}$ ed., Vallabh Prakashan, New Delhi 1999, pp. 95-97.

12. S. H. Bodakhe, J. S. Dangi, A. Ram, K. P. Namdeo and K. S. Bodakhe, Isolated cock ileum: A tool for pharmacology experiments, Indian J. Pharm. Educ. Res. 43 (2009) 199-202.

13. L. Ustunfs, G. M. Laekeman, B. Gozler, A. J. Vlietinck, A. Ozer and A. G. Herman, In vitro study of the anticholinergic and antihistaminic activities of protopine and some derivatives, J. Nat. Prod. 51 (1988) 1021-1022; DOI: 10.1021/np50059a043.

14. N. Chand, W. Diamantis and R. D. Sofia, Antagonism of histamine and leukotrienes by azelastine in isolated guinea pig ileum, Agents Actions 19 (1986) 164-168; DOI: 10.1007/BF01966201.

15. V. C. Filho, J. A. Zampirolo, H. K. Stulzer and V. Schlemper, Antispasmodic effects of Persea cordata bark fractions on guinea pig ileum, Fitoterapia 78 (2007) 125-128; DOI: 10.1016/j.fitote. 2006.10.005.

16. G. D. Carlo, N. Mascalo, A. A. Izzo and F. Capasso, Effects of quercetin on the gastrointestinal tract in rats and mice, Phytother. Res. 8 (1994) 42-45; DOI:10.1002/ptr.2650080110.

17. S. Chittrakarn, K. Sawangjaroen, S. Prasettho, B. Janchawee and N. Keawpradub, Inhibitory effects of kratom leaf extract (Mitragyna speciosa Korth) on the rat gastrointestinal tract, J. Ethnopharmacol. 116 (2008) 173-178; DOI: 10.1016/j.jep.2007.11.032.

18. S. Sasidharan, L. Yogalatha, Z. Zuraini, S. Suryani, S. Sangetha and L. Shirley, Antidiarrheal and antimicrobial activities of Stachytarpheta jamaicensis leaves, Indian J. Pharmacol. 39 (2007) 245-248; DOI: $10.4103 / 0253-7613.37276$.

19. A. Robert, J. E. Nezamis, C. Lancaster, A. J. Hanchar and M. S. Klepper, Enteropooling assay; a test for diarrhea produced by prostaglandins, Prostaglandins 11 (1976) 809-828; DOI: 10.1016/0090-6980(76)90189-1.

\author{
$S A \check{Z} E T A K$
}

\title{
Sinteza, spazmolitsko i antidijaretsko djelovanje nekih 1-supstituiranih derivata imidazola
}

BASKAR LAKSHMANAN, PAPIYA MITRA MAZUMDER, DINAKAR SASMAL i SWASTIKA GANGULY

U radu je opisana sinteza serije novih 1-supstituiranih imidazola 1a-d i 2a-d te evaluacija njihovog spazmolitskog i antidijaretskog djelovanja. Spazmolitsko djelovanje različith koncentracija ispitivanih spojeva $\left(10,50 \mathrm{i} 100 \mu \mathrm{g} \mathrm{mL} \mathrm{m}^{-1}\right)$ ispitano je na izoliranim tkivnim preparatima; krivulje ovisnosti djelovanja o koncentraciji uspoređene su s djelovanjem atropina. Svi ispitivani spojevi inhibirali su kontrakcije ileuma zamorca. Dijarea inducirana ricinusovim uljem u štakora korištena je za vrednovanje antidijaretskog djelovanja. Intestinalni prijenos i volumen intestinalne tekućine mjereni su pri dozi 
B. Lakshmanan et al:: Synthesis, antispasmodic and antidiarrheal activities of some 1-substituted imidazole derivatives, Acta Pharm. 61 (2011) 227-236.

od $40 \mathrm{mg} \mathrm{kg}^{-1}$ i uspoređeni s učinkom standarda loperamida (doza $6 \mathrm{mg} \mathrm{kg}^{-1}$ ). Učestalost defekacije $\mathrm{u}$ testiranoj skupini bila je značajno niža $(p<0,01) \mathrm{u}$ usporedbi s kontrolnom skupinom i standardom. Provedena ispitivanja pokazuju da antidijaretsko djelovanje ispitivanih spojeva može biti posljedica inhibicije intestinalnih pokreta i redukcije kapilarne permeabilnosti u abdominalnoj šupljini.

Ključne riječi: 1-supstituirani imidazoli, spazmolitik, antidijaretik, gastrointestinalni prijenos Department of Pharmaceutical Sciences

Birla Institute of Technology, Mesra, Ranchi, Jharkhand-835215, India 